\title{
Adversity Quotient pada Pelaku Startup di Yogyakarta: Kegigihan di Tengah Masalah
}

\author{
Akbar Verezha Bintang Ibrahim ${ }^{1}$ \& Sumaryono ${ }^{2}$ \\ Fakultas Psikologi Universitas Gadjah Mada
}

\begin{abstract}
The purpose of this research was to understand the adversity quotient among startup founders in Yogyakarta. Phenomenology was the approach and analyzed by Miles and Huberman interactive model. The data collection method in this research was semistructured interview. Respondents in this study consisted of three startup founders with these criteria: 1) aged 18-24 years old, 2) age of startup at least 1 year, 3) based in Yogyakarta, 4) willing to be interviewed. This study found two forms of adversity quotient on startup founders: 1) coping strategies and 2) characters. Coping strategies encompassed immediate problem solving, having goals and visions, taking lessons from problems, and finding solutions. While the characters consisted of concepts such as responsibility, learning from experience, having strong principles, persistence, and optimism.
\end{abstract}

Keywords : adversity quotient; character; coping strategy; persistence; startup

Abstrak. Tujuan penelitian ini untuk mengetahui bagaimana adversity quotient pelaku startup di Yogyakarta. Pendekatan yang digunakan adalah fenomenologi dan dianalisis dengan model interaktif Miles dan Huberman. Metode pengambilan data menggunakan wawancara semi terstruktur dengan pedoman wawancara yang dibuat oleh peneliti. Berdasarkan hasil penelitian, ditemukan dua bentuk adversity quotient pada pelaku startup, yaitu strategi coping dan karakter. Strategi coping mencakup menyelesaikan masalah dengan segera, memiliki tujuan dan visi, mengambil hikmah, dan mencari solusi. Karakter pada pelaku startup mencakup beberapa konsep seperti bertanggung jawab, belajar dari pengalaman, teguh pada prinsip, pantang menyerah, dan optimis.

Kata kunci : adversity quotient; karakter; kegigihan; startup; strategi koping

Perusahaan rintisan atau biasa dikenal dengan startup saat ini menjadi salah satu fokus Pemerintah Indonesia agar tidak tertinggal dengan negara-negara lain (Budiman, 2016). Startup adalah perusahaan yang baru saja dijalankan dan usianya belum genap 5 tahun (Sari \& Sitepu, 2016). Tercatat jumlah startup di Indonesia di tahun 2016 berkisar di angka 2.000. Jumlah tersebut merupakan yang tertinggi di Asia Tenggara. Jumlah startup di Indonesia diperkirakan akan meningkat jumlahnya hingga 13.000 pada tahun 2020 (Kure, 2016).

Startup bisa menjadi salah satu upaya alternatif pemerintah dalam mengurangi angka pengangguran (Shohib, 2013). Dalam sebuah survei yang dilakukan oleh Global Entrepreurship Monitor di tahun 2014 menunjukkan bahwa generasi muda

\footnotetext{
1 Korespondensi mengenai isi artikel ini dapat

dilakukan melalui verezha@gmail.com

2 atau melalui sumaryono.cendix@ugm.ac.id 
di Indonesia sudah memiliki keinginan untuk membuat startup. Sebesar $41 \%$ responden perempuan dan 34,3\% responden laki-laki bahkan sudah memiliki startup sendiri di usia antara 25 34 tahun. Mayoritas di Indonesia, orangorang memutuskan untuk memulai sebuah startup setelah menyelesaikan Sekolah Menengah Atas (SMA) dengan persentase laki-laki 59,1\% dan perempuan 56,2\% (Nawanglupi et al., 2015).

Sebagai suatu usaha yang sedang dirintis, startup rentan akan kegagalan. Startup kerap menghadapi masa-masa kritis pada usia 1-5 tahun petama (Sari \& Sitepu, 2016). Administrasi U. S Small Business menunjukkan bahwa sebesar $71 \%$ bisnis gagal dalam waktu empat tahun dan $85 \%$ gagal di tahun kelima (Sine, Haveman, \& Tolbert, 2005). Tidak jauh berbeda dengan di Indonesia, Hari Sungkari sebagai Deputi Bidang Infrastruktur Badan Ekonomi Kreatif, menjelaskan tingkat kegagalan startup di Indonesia mencapai angka 90\% (Yusuf, 2016).

Echdar menjelaskan bahwa faktorfaktor internal yang dapat menyebabkan kegagalan dalam menjalankan startup antara lain kurangnya komitmen untuk mencapai kesuksesan dalam diri pendiri startup, perencanaan yang kurang matang, pengelolaan uang yang kurang baik, dan manajemen yang tidak tegas (dalam Sari \& Sitepu, 2016). Selain itu, faktor eksternal seperti peran pemerintah juga memiliki andil dalam kegagalan startup. Contohnya di Yogyakarta, kurangnya pemahaman dan perhatian tentang startup berbasis digital membawa efek negatif. Untuk bisa mengembangkan startup berbasis digital, dibutuhkan dukungan lebih dari infrastruktur seperti koneksi internet yang memadai dan peraturan perlindungan pada startup lokal agar bisa bersaing dengan produk luar negri (Fathin, Achidsti, \& Priambodo, 2016).
Dampak dari kegagalan startup dapat berakibat buruk bagi sang pendiri. Mendapatkan tekanan besar seperti itu dapat menyebabkan depresi. Banyak dari mereka yang tidak mengutarakan ini karena merasa takut akan kegagalan (Harbison, 2014). Kegagalan dapat menyebabkan pengalaman emosional dan traumatis (Cope, 2011). Apabila harga dari kegagalan yang didapat (keuangan, sosial, dan psikologis) terlalu besar dibandingkan dari pelajaran yang didapat dari kegagalan, para pelaku startup memilih untuk tidak melanjutkan aktivitas dalam dunia usaha (Ucbasaran et al., 2013). Dikutip dari website Business Insider (Shontell, 2013), seorang pendiri startup Ecomom bernama Jody Sherman ditemukan bunuh diri setelah startup miliknya tersebut bangkrut. Kegagalan Jody Sherman menjalankan startup-nya tersebut diketahui karena ketidakmampuannya mengatur keuangan (Shontell, 2013).

Untuk menghadapi tantangan dan tekanan akan kegagalan dibutuhkan kekuatan untuk menghadapinya, Stoltz (2000) berpendapat bahwa salah satu kekuatan yang dibutuhkan adalah seberapa jauh individu mampu bertahan menghadapi tekanan dan kemampuan untuk mengatasinya atau disebut dengan adversity quotient. Stoltz (2000) menjelaskan adversity quotient adalah daya juang seseorang dalam menghadapi kesulitan atau ketahanan seseorang menghadapi situasi yang menekan. Jika tidak memiliki adversity quotient yang tinggi maka dikhawatirkan para pendiri startup mudah mengalami frustasi saat mengalami masamasa sulit menjalankan startup (Shohib, 2013). Hal terpenting ketika mereka gagal, mereka tidak hanya belajar dari kegagalan, namun juga tetap positif dan termotivasi melalui adversity quotient yang kuat (Markman \& Baron, 2003). Adversity quotient telah terbukti berkontribusi dalam 
keberhasilan berwirausaha (dalam penelitian ini adalah startup) karena memungkinkan para pelaku startup bertahan dalam usaha tersebut (Overall \& Wise, 2016). Melalui ketekunan mereka, para pelaku startup dapat belajar dari kegagalan yang dialami dan membantu mereka dalam usaha yang dijalankan berikutnya (Huovinen \& Tihula, 2008).

Terlibat dalam dunia startup yang penuh dengan risiko, membutuhkan ketahanan dan adversity quotient yang baik untuk bisa meraih kesuksesan. Bahkan Harbison (2014) menyebutkan bahwa kegagalan adalah hal yang hampir pasti dilalui dalam dunia startup. Mereka yang mudah menyerah akan mengalami kegagalan, namun bagi mereka yang gigih dan mampu menghadapi masa-masa sulit dapat terus melanjutkan startup-nya. Oleh karena itu, hal ini mendorong peneliti untuk mencari tahu adversity quotient pada penlaku startup dalam menghadapi masalah-masalah selaman menjalankan startup.

\section{Metode}

Responden penelitian dipilih dengan metode purposive sampling. Purposive sampling dipilih karena merupakan teknik yang berdasarkan pada ciri-ciri yang dimiliki oleh responden yang dipilih, karena ciri-ciri tersebut sesuai dengan tujuan penelitian yang akan dilakukan. Strategi yang digunakan dalam purposive sampling adalah typical sampling yang merupakan strategi untuk kasus-kasus bersifat unik atau khas atau indiviuindividu yang memiliki karakteristik unik (Herdiansyah, 2015). Adapun kriteria inklusivitas responden yang dipertimbangkan dalam penelitian ini yaitu; 1.) berusia 18 - 24 tahun, 2.) usia startup berbasis digital yang dijalankan minimal satu tahun dan masih aktif berjalan hingga penelitian ini dilakukan,
3.) startup berdomisili di Yogyakarta, 4.) bersedia dengan sukarela dan tanpa paksaan mengikuti penelitian dari awal hingga akhir.

Metode yang digunakan untuk mengumpulkan data dalam penelitian kualitatif bisa melalui wawancara, observasi, dokumentasi, dan trianggulasi data (Sugiyono, 2008). Metode yang digunakan dalam penelitian ini adalah wawancara. Wawancara adalah proses memperoleh informasi dengan cara tanya jawab sambil bertatap muka antara pencari informasi dengan responden atau narasumber, dengan atau tanpa pedoman pertanyaan wawancara (Bungin, 2001). Menggunakan wawancara dalam penelitian kualitatif maka peneliti dapat memahami dunia dari sudut pandang responden, membuka arti dari pengalaman hidupnya, dan juga untuk membuka kehidupannya lewat kacamata ilmiah (Brinkmann \& Kvale, 2015). Wawancara yang digunakan dalam penelitian ini adalah semi terstruktur. Ciriciri dari wawancara semi-terstruktur adalah pertanyaan terbuka namun ada batasan pada tema dan alur pembicaraan, kecepatan wawancara dapat diprediksi, dan ada pedoman wawancara yang dapat dijadikan patokan dalam alur, serta tujuannya adalah untuk memahami suatu fenomena (Herdiansyah, 2015).

Teknik analisis data yang digunakan dalam penelitian ini adalah model interaktif menurut Miles \& Huberman (1994). Tahapan-tahapan beserta alur teknis analisis model interaktif menurut Miles \& Huberman adalah 1) pengumpulan data, 2) reduksi data, 3) penyajian data, dan 4) kesimpulan atau verifikasi.

Pada saat peneliti melakukan pendekatan dan berkomunikasi dengan responden, melakukan observasi, membuat catatan lapangan, itu semua merupakan proses pengumpulan data 
yang nantinya akan diolah. Sepanjang penelitian dilakukan, maka sepanjang itu pula proses pengumpulan data dilakukan.

Reduksi data merupakan penggabungan dan penyeragaman data yang diperoleh menjadi satu bentuk tulisan yang akan dianalisis. Pada penelitian ini maka hasil wawancara akan diolah menjadi verbatim wawancara.

Setelah data-data yang diperoleh telah diformat atau diubah sesuai dengan instrumen pengumpul data dan telah berbentuk tulisan, langkah berikutnya adalah penyajian data. Penyajian data yaitu mengolah data setengah jadi yang sudah seragam ke dalam matriks kategorisasi sesuai tema-tema yang sudah dikelompokkan dan dikategorikan, serta akan memecah tema-tema tersebut ke dalam bentuk yang lebih konkret dan sederhana yang disebut dengan sub-tema, yang diakhiri pemberian kode dari subtema tersebut.

Kesimpulan dalam rangkaian analisis ini secara esensial berisi tentang uraian dari seluruh sub-kategorisasi tema yang tercantum pada tabel kategorisasi dan koding yang sudah diselesaikan.

\section{Hasil}

Terdapat tiga responden dalam penelitian ini, yaitu KR, AM, dan RF. KR menjadi responden pertama yang peneliti temui untuk pengambilan data, tepatnya tanggal 24 Mei 2017. KR merupakan seorang perempuan yang menjadi CEO sebuah startup yang sudah berjalan sekitar dua tahun. RF merupakan seorang laki-laki yang menjadi CEO sebuah startup yang sudah berjalan sekitar dua tahun. AM merupakan responden laki-laki yang menjadi CTO sebuah startup yang sudah berjalan sekitar satu tahun. Peneliti melakukan pengambilan data berupa wawancara masing-masing 3 kali pada tiap responden.
Terdapat enam tema besar yang ditemukan dalam diri responden $\mathrm{KR}$, yaitu penyebab masalah dalam menjalankan startup, dampak masalah pada responden, strategi coping, strategi dalam mengembangkan startup, dukungan sosial, dan karakter. Selama lebih dari satu tahun menjalankan startup, KR menceritakan bahwa ia mendapatkan berbagai masalah yang harus dihadapinya. Masalah tersebut menurutnya disebabkan oleh banyak faktor. Bisa disebabkan oleh dirinya sendiri, faktor internal tim, dan faktor eksternal. Dampak masalah yang dihadapi oleh KR berpengaruh pada perasaan dan tenaganya. KR menjelaskan bahwa ketika menghadapi permasalahan tim internal yang sempat bergonta-ganti anggota, dirinya merasa sedih. Masalah ekternal yang muncul dari program inkubasinya juga membuat perasaanya tak menentu. Selain itu ia juga merasakan lelah fisik karena ritme jadwal yang tidak bekerja sebagaimana mestinya. KR menjelaskan ia beberapa kali kelelahan menghadapi masalah-masalah tersebut.

Dalam menghadapi masalahmasalah tersebut, KR melakukan strategistrategi, baik strategi menyelesaikan masalah maupun strategi untuk mengembangkan startupnya. Strategi ini merupakan perwujudan aspek dari adversity quotient berupa control dan endurance. Saat menghadapi masalah berupa anggota tim yang silih berganti, KR memutuskan untuk langsung menawari teman-temannya bergabung di timnya. Selain itu KR juga merasa penting untuk mengajak berdiskusi jika menghadapi masalah. Sebelum berdiskusi pun biasanya KR juga sudah menyiapakan solusi untuk ditawarkan.

Perwujudan adversity quotient KR juga dilihat dari karakter. KR memiliki karakter bertanggung jawab, optimis, mampu belajar dari pengalaman, dan bisa memotivasi diri sendiri. Sebagai seorang 
CEO, KR memiliki rasa tanggung jawab yang tinggi atas apa yang ia kerjakan dan juga atas nasib dari teman-temannya. KR menyadari dirinya mengemban tugas yang lebih besar sebagai seorang pemimpin sehingga besar pula tanggung jawab yang ia punya. KR juga optimis dengan kemampuannya untuk membawa startupnya lebih baik. Ia merasa yakin dengan dirinya sendiri. Walaupun ia mengutarakan belum tentu mengetahui cara yang tepat unutk menyelesaikan masalah, setidaknya ia merasa mampu dulu. KR juga memiliki pengalaman usaha sebelumnya yang kemudian hal tersebut memberikan pengaruh baginya dalam menentukan keputusan dan kebijakan yang harus ia ambil. KR menyadari bahwa ia banyak belajar dari pengalaman usaha sebelum menjalankan startup. KR juga memotivasi dirinya ketika ada masalah. Ia menjelaskan ketika dia memiliki tujuan dan visi yang jelas, ia termotivasi untuk menghadapi masalah.

Selain itu, dukungan sosial memberikan pengaruh bagi KR. Dukungan sosial pertama datang dari tim inernalnya. Walaupun sempat beberapa kali berganti anggota, KR merasa saat ini timnya lebih menunjukkan komitmen dan kesngguhan. KR juga mendapatkan fasilitas tempat dan wifi dari program inkubasi tempatnya bernaung. Dengan begitu KR memiliki kantor tetap untuk startup-nya. Hal ini menguntungkan bagi KR karena dapat meningkatkan rasa percaya konsumen kepada startupnya. Dukungan juga datang dari instansi pemerintahan. KR menceritakan bahwa startupnya diajak bekerjasama menciptakan sebuah program. KR merasa hal ini dapat memberikan keuntungan bagi dirinya dan startupnya.

Terdapat lima tema besar yang ditemukan pada diri responden AM, yaitu peenyebab masalah dalam menjalankan startup, dampak masalah pada responden, strategi koping, strategi mengembangkan startup, dan karakter. Selama menjalankan startup, AM merasakan banyak masalah yang dialami. Hal itu terkait dengan masalah dalam tim itu sendiri, masalah finansial, masalah eksternal, dan juga masalah yang datang dari dirinya sendiri. AM menyoroti masalah dalam timnya yang muncul karena kurangnya kekompakan masing-masing anggota. AM melihat tiap anggota kurang menunjukkan komitmen pada startup, seperti sulit dihubungi, pekerjaan tidak selesai tepat waktu, dan juga sulit untuk ditemui. Menurut AM hal itu dikarenakan masingmasing anggota punya kesibukan yang lain. Bagi AM masalah ini jelas menghambat kinerja tim.

Dampak dari masalah sangat dirasakan oleh AM. Masalah yang terjadi membuat merasa pesimis dengan keberlangsungan startup-nya. Ia menyoroti kekompakan timnya yang dianggap masih kurang. Ia tidak begitu yakin kalo startupnya ini bisa berjalan dengan baik ke depannya. Ditambah lagi menurutnya ia belum menemukan model bisnis yang tepat. Ia juga merasakan kecemasan dengan kondisi startup-nya yang seperti itu. AM juga mengakui bahwa aktivitas lain di luar startup menjadi terganggu. Aktivitas tersebut yang dimaksud adalah kuliah. AM memang memprioritaskan sebagian besar waktunya untuk startup, oleh karena itu ia merasa intensitas aktivitas yang lain menjadi menurun.

Untuk menyelesaikan masalahmasalah tersebut, AM melakukan caracara atau strategi yang merupakan perwujudan dari adversity quotient. AM merasa bahwa masalah yang dihadapi harus segera diselesaikan. Hal ini ia jelaskan bahwa dirinya sebisa mungkin segera menyelesaikan tugas-tugas agar tidak menjadi masalah baru nantinya. Ia tidak mau jika nanti tugasnya menjadi terbengkalai dan menghambat kerja 
anggota lain. Selain itu menceritakan bahwa ia menjaga komunikasi dengan anggota lain saat ada masalah. Selain itu ia menceritakan bahwa tim startup lain juga membantunya memberi saran. Hal ini karena startup lain juga pernah mengalami masalah serupa. AM juga menceritakan bahwa timnya juga rutin mengadakan evaluasi kinerja tim. Selain itu, ada juga evaluasi menyeluruh setiap tiga bulan.

Perwujudan adversity quotient AM juga dilihat dari karakternya. AM adalah orang yang belajar dari pengalaman, khususnya saat menghadapi masalah. Ia menceritakan pengalaman menghadapi masalah yang membuatnya belajar dan merasa semakin mampu untuk menyelesaikan masalah. AM juga merupakan orang yang bertanggung jawab. Meskipun AM bukan berposisi sebagai CEO, ia merasa juga memiliki tanggung jawab ikut menyelesaikan masalah. Baginya apabila ia bisa menangi sendiri masalahnya, ia tak perlu bantuan dari orang lain.AM juga menunjukkan karakter tidak takut gagal. AM memang memiliki pengalaman gagal dengan startup sebelumnya. AM melihat apabila nantinya startup yang sekarang ini gagal, itu bukan menjadi masalah baginya. Menurut AM yang terpenting ia bisa mengambil pelajaran dan pengalaman. Ia juga menambahkan bahwa memang startup yang sekarang bukan merupakan tujuan akhir.

Terdapat lima tema besar yang ditemukan pada diri responden RF, yaitu penyebab masalah dalam menjalankan startup, dampak masalah pada responden, strategi coping, dukungan sosial, dan karakter. Selama dua tahun menjalani startup, RF menemui masalah yang muncul dari dalam dirinya sendiri, tim internal, dan juga lingkungan keluarga. Masalah yang dihadapi karena bersumber dari dirinya sendiri menurutnya sering ia alami. Hal ini tak lepas dari peranannya sebagai seorang pemimpin di startup-nya yang mana ia memikul tugas yang lebih berat dan kompleks.

Dampak dari masalah-masalah yang dihadapi RF diraskan pada aktivitas, pikiran, dan perasaannya. Tanpa menyebutkan permasalahannya, RF menjelaskan bahwa masalah yang dihadapi cukup mengganggu aktivitas di luar startup-nya. RF menyatakan bahwa ia menjadi kepikiran pada masalah yang dihadapi saat sedang mengerjakan hal lain. Alhasil RF harus memompa semangat yang lebih untuk menjalani aktivitasnya yang lebih. FR menceritakan bahwa karena masalah yang dihadapinya, ia merelakan aktivas yang lain tidak berjalan sesuai rencana. Selain itu, RF juga merasa bahwa waktu dan tenaga yang ia curahkan untuk startup-nya masih belum sepadan dengan hasilnya. RF merasa kadang ia tidak bersamangat ketika apa yang diusahakannya tidak sebanding dengan hasilnya sementara ia melihat temannya lain secara usaha lebih kecil dengan bekerja di kantor namun mendapatkan hasil yang lebih baik.

Dalam menyelesaikan masalahmasalahnya, RF menunjukkan adversity quotient yang terwujud dalam strategi coping. RF melakukan beberapa cara untuk menyelesaikan masalah atau untuk menenangkan dirinya. Ketika RF mengetahui masalah berupa anggota tim yang sering berganti, ia mencoba untuk mempertahankan mereka. Proses tersebut dilakukan dengan menanyakan kembali alasan, tujuan, dan visi mereka berada di startup tersebut. Bagi RF, memiliki tujuan dan visi penting untuk menjaganya tetap bersemangat. Ketika RF merasa down dan tidak bersemangat, ia mengingat kembali apa tujuan dan visinya. Hingga sejauh ini RF merasa belum bisa merealisasikannya sehingga ia tidak mau mudah menyerah dan patah semangat. 
Wujud lain dari adversity quotient RF adalah karakter. RF menyadari bahwa ia orang yang memiliki jiwa sosial yang tinggi. Hal ini merupakan buah dari didikan orangtuanya. Memiliki jiwa sosial ini juga menjadi awal mula ide startup miliknya. RF menjelaskan bahwa ia ingin berguna dan memberi manfaat bagi orang lain. Ingin bermanfaat bagi orang lain merupakan alasannya mendirikan startup. Hal itu pula yang membuat dirinya tidak mau mudah menyerah menjalankan startup-nya. RF juga memiliki pandangan jauh ke depan. Ia sudah merencanakan untuk menjual startup-nya atau menawarkan diakuisisi saat lima tahun yang akan datang. Hal inilah yang membuatnya bersemangat untuk membesarkan startup-nya dalam lima tahun ini. RF memberikan alasan ingin menjual startup karena ada hal yang masih ingin ia raih. Meskipun sebenarnya saat ini sudah ada beberapa pihak yang tertarik untuk mengakuisisi startup-nya, RF masih menolak. Sebagai seorang CEO, RF merasa memiliki tanggung jawab atas timnya. Hal itu ia jelaskan dengan rasa ingin memberikan gaji bagi timnya. Ia ingin bisa memberikan penghasilan bagi orangorang yang selama ini sudah bekerja bersamanya. Menurutnya itulah tanggung jawab seorang CEO. Selain itu RF juga menyadari batas kemampuannya. Ia menjelaskan bahwa ia tidak tertarik dengan bidang manajamen operasional. Ia merasa itu bukan keahliannya. Namun mengetahui bahwa startup-nya sedang menuju hal yang lebih komplek dan membutuhkan hal yang berkaitan dengan operasional, ia memutuskan untuk mempelajarinya. Walaupun baginya hal tersebut bukan hal yang disenanginya, ia mau belajar.

Perwujudan adversity quotient RF dipengaruhi oleh dukungan sosial. RF menceritakan bahwa selama menjalankan startup ia menerima dukungan dari berbagai pihak. Ia pernah mendapat kesempatan oleh pihak kampusnya untuk melakukan konfrensi pers untuk launching startup-nya. Selain itu ia juga mendapatkan fasilitas tempat berupa kantor yang bisa ia gunakan untuk startup-nya. Selain itu, RF juga aktif mengikuti acara-acara seputar startup. Melalui acara tersebut, RF mengaku bahwa ia mendapat dukungan dengan ditawari pendanaan oleh beberapa investor.

\section{Diskusi}

Menjalankan sebuah startup bukanlah hal yang mudah karena usaha yang dirintis tersebut pasti akan menemui kendala atau masalah dalam proses berkembangnya. Dibutuhkan kegigihan dan kemauan untuk mengatasi masalah-masalah yang dihadapi agar startup dapat terus berjalan. Stoltz menyebutkan bahwa adversity quotient atau daya juang disebut sebagai kunci kesuksesan untuk mengatasi masalah-masalah yang dialami. Pembahasan ini bertujuan untuk mengetahui bagaimana adversity quotient pada pelaku startup.

Peneliti menemukan kesamaan bentuk adversity quotient yang diperlihatkan ketiga responden. Bentuk adversity quotient tersebut tertuang dalam karakter diri dan cara coping responden terhadap masalah. Karakter pada ketiga responden yang ditemukan pada peneliian ini adalah bertanggung jawab, belajar dari pengalaman, teguh pada prinsip, pantang menyerah, dan optimis. Strategi coping yang muncul pada ketiga responden adalah segera menyelesaikan masalah, memiliki tujuan dan visi, mengambil hikmah dari masalah, dan mau mencari solusi. Sebelum lebih dalam pembahasan terkait bentuk adversity quotient, peneli terlebih dahulu akan membahas faktorfaktor lain yang memengaruhi terbentuknya adversity quotient. 
Ketiga responden memiliki kesamaan yaitu masalah yang dihadapi dalam menjalankan startup. Dalam menjalankan startup memang tidak akan lepas dari kendala atau kesulitan, baik yang muncul dari dalam internal tim maupun di luar tim. faktor masalah dalam menjalankan startup. Masalah bisa bersumber dari beberapa pihak. Pertama, ketiga responden merasa penyebab masalah muncul dari faktor tim internal atau tim startup itu sendiri. $\mathrm{KR}$ menjelaskan masalah yang dialaminya disebabkan oleh anggota tim nya beberapa kali mengalami pergantian sehingga membuat kinerja tim menjadi terhambat. Selain itu, KR juga kehilangan figur Chief Technology Officer (CTO) sehingga proses startup-nya masih belum maksimal. Sementara AM menjelaskan bahwa penyebab masalah muncul dari tim startupnya saat ini dirasa kurang kompak dan kurang menujukkan komitmen sehingga kinerja jadi begitu lamban bahkan beberapa pekerjaan terbengkalai. Menurut $\mathrm{AM}$, penyebab ini yang masih menjadi pekerjaan rumah paling besar bagi startupnya. Sementara RF juga menjelaskan penyebab munculnya masalah terjadi karena perbedaan visi dan tujuan di dalam timnya sehingga beberapa kali terjadi pergantian tim. Selain itu menurut RF masalah juga muncul karena sulitnya mengatur ego masing-masing anggota, ditambah lagi kurangnya pemahaman pembagian peran job desc.. Penyebab dari masalah-masalah internal dalam startup ini seperti yang sudah disampaikan oleh Fredland \& Morris (1976) yaitu masalah pada startup dapat disebabkan dari faktor endogen seperti urusan internal dalam mengelola tim..

Ketiga responden juga menilai bahwa diri mereka sendiri mempunyai kontribusi sebagai penyebab terjadinya masalah. Masalah yang muncul dari sendiri ini tak terlepas dari keterbatas kemampuan dan keahlian dalam hal tertentu. KR menjelaskan bahwa masalah yang datang dari dirinya sendiri adalah kesalahan yang ia buat dalam memilih keputusan, sehingga progres startup-nya terasa lambat dalam setahun ke belakang. Perannya sebagai seorang CEO membuatnya memiliki kewenangan lebih untuk mengambil keputusan dan kebijakan, namun peran tersebut masih terkendala keterbatasan kemampuan pada dirinya. Sementara AM menjelaskan bahwa masalah yang muncul dari dirinya adalah keterbatasan pengetahuan menggunakan teknologi. Teknologi memang sudah menjadi tanggung jawab AM karena dirinya adalah seorang CTO. Keterbatasan pemahaman itu yang membuat pekerjaan jadi lambat dikerjakan dan menghambat pekerjaan anggota yang lain. Bagi RF, meskipun tak menjelaskan lebih detail tentang apa masalah yang muncul dari dirinya sendiri, namun ia mengaku bahwa ia juga tak lepas dari kesalahan terlebih lagi posisinya sebagai seorang CEO yang memikul peran yang lebih besar. Masalah-masalah yang disebabkan dari dalam diri sendiri tersebut dijelaskan oleh Everett dan Watson (1998) bahwa penyebab masalah atau kegagalan startup itu muncul karena kurangnya keterampilan manajemen.

Selain masalah yang muncul dari dalam diri startup itu sendiri, hasil temuan juga menunjukkan ketiga responden mendapatkan masalah yang disebabkan dari luar startup. Bagi responden KR dan AM, keduanya menyebutkan bahwa masalah disebabkan dari tugas yang diberikan oleh program inkubasi tempat startup mereka bernaung. Tugas yang diberikan tersebut dirasa kurang sejalan dengan progres startup itu sendiri sehingga membuat jadwal yang berbenturan. KR menceritakan bahwa konsentrasinya terpecah untuk mengerjakan dua kegiatan sekaligus, yaitu tugas dari program 
inkubasi dan tujuan yang ingin dicapai startup-nya. Tak jauh berbeda dengan KR, AM merasa bahwa tugas dari program inkubasi sangat menyita waktu. Tujuan yang ingin dicapai startup-nya bahkan disebutkan sampai terbengkalai dan tidak berhasil karena sibuk menyelesaikan tugas tersebut. Sementara RF mengalami masalah dari lingkungan keluarganya yang menuntut RF untuk mendapatkan penghasilan lebih baik. Hal Ini karena RF sebelumnya pernah memiliki pekerjaan yang mendapat penghasilan yang lebih baik dari sekarang. Masalah-masalah yang disebabkan oleh faktor eksternal yang dialami oleh ketiga responden juga dijelaskan oleh Fredland \& Morris (1976) bahwa masalah startup juga dapat muncul dari luar kendali individu atau biasa disebut dengan faktor eksogen.

Selain masalah internal, diri sendiri, dan eksternal, responden AM menjelaskan bahwa salah satu masalah utama yang dialam startup-nya disebabkan oleh masalah finansial. AM menjelaskan hingga kini startup mereka masih terus berusaha dengan uang masing-masing. Hal ini yang menurutnya dirasa akan memberatkan karena ada yang hidupnya sudah tidak dibiyai orangtuanya lagi. Masalah finansial seperti ini juga dijelaskan oleh Everett dan Watson (1998) bawah modal yang tidak memadai dapat menimbalkan masalah. Berbeda dengan kedua responden yang tidak mengalami masalah secara finansial. KR sendiri di luar startupnya juga memiliki pekerjaan lain sehingga baginya finansial bukan masalah pada saat ini. Begitupula dengan RF yang memiliki project lain di luar startup-nya. RF sendiri menjelaskan bahwa startup-nya tidak terkendala dana karena sudah beberapa kali ditawarkan investasi oleh beberapa investor.

Masalah-masalah yang dihadapi oleh ketiga responden memberikan dampak kurang baik pada aktivitas dan kegiatan lain di luar startup. Dampak tersebut dirasakan pada segi fisik, pikiran, dan perasaan. KR menjelaskan bahwa dampak masalah yang dihadapinya menimbulkan perasaan yang jadi tak menentu, antara emosi positif dan negatif. Selain itu ia juga merasakan fisiknya menjadi lelah dan letih karena harus menyelesaikan masalah-masalah tersebut. Namun baginya, ia tetap mampu fokus beraktivitas di luar startup karena adanya faktor lain seperti pengalaman terdahulunya. Bagi AM, dampak masalah yang dirasakannya ia menjadi pesimis dengan startup-nya. Ia ragu usia startupnya dapat berumur panjang dikarenakan kurang kompaknya tim internal. AM juga menjelaskan bahwa aktivita di luar startupnya menjadi terganggu, karena saat ini ia juga sedang mengerjakan skripsi. Hal ini dikarenakan AM meluangkan sebagian besar waktunya untuk startup, sehingga aktivitas lain menjadi di kesampingkan. Sementara RF, merasakan dampak maasalah seperti aktivitas dan pikirannya terganggu. Ini juga dikarenakan RF meluangkan sebagian besar waktunya untuk startup, sehingga ketika startup-nya mengalami kendala, hal tersebut berdampak pada aktivitas lain. Dampakdampak masalah yang dirasakan oleh responden merupakan perwujudan atau bentuk dari dimensi reach (jangkauan) dalam adversity quotient. Stoltz (2000) menjelaskan bahwa reach menunjukkan sejauh mana kesulitan yang dihadapi responden merambah pada aktivitas lain. Dari pembahasan sebelumnya ditemukan hasil bahwa masalah pada startup memberikan dampak khusus bagi aktivitas responden di luar startup.

Cara menyikapi atau strategi coping pada masalah merupakan bentuk dari adversity quotient yang dimiliki oleh responden KR, AM, dan RF. Menghadapi masalah internal berupa anggota tim yang beberapa kali berganti, disikapi KR dengan 
baik. Saat ditinggal oleh beberapa anggotanya, KR bergerak untuk merekrut anggota baru dengan cara mengajak teman-teman dari startup lain yang startupnya tidak berjalan. KR menunjukkan bahwa ia memiliki kendali atas masalahnya dan tau bahwa ia harus segera menyelesaikannya. RF saat menghadapi situasi anggota yang memilih untuk keluar, ia menjelaskan bahwa ia mencoba untuk mempertahankan anggotanya terlebih dahulu. Ia ingin mengingatkan lagi apa tujuan, visi, dan alasan anggotanya berada di startup. Ia masih mengusahakan agar anggotanya bertahan. Walaupun pada akhirnya RF tidak bisa memaksakan untuk menahan anggotanya karena tidak mungkin berjalan dengan perbedaan tujuan.

KR dan RF menunjukkan aspek kendali yang baik dalam adversity quotient. Sebagai seorang CEO, KR dan RF menujukkan perilaku yang baik dalam mengendalikan tim. Berbeda dengan AM yang merupakan seorang CTO. Menurutnya kekompakan tim yang kurang adalah tugas seorang CEO. Walaupun begitu ia tetap membantu menjaga keutuhan dan kelancaran tim. AM mencoba untuk tidak memperburuk masalah yang terjadi dengan segera menyelesaikan apa yang menjadi tugasnya. Dengan begitu ia tidak menghambat pekerjaan anggota lain. Ini menunjukkan kendali AM dalam menghadapi masalah. Stoltz (2000) menjelaskan bahwa aspek adversity quotient adalah kendali (control) yang artinya menunjukkan respon individu meghadapi masalah. Individu yang merasa punya kendali atau bisa merespon situasi yang sulit menujukkan ia memiliki adversity quotient yang tinggi. Dalam temuan ini, KR dan RF lebih menujukkan kendali yang lebih tinggi atas masalah ketimbang AM. Perbedaan kendali yang ditunjukkan AM karena peran dan posisi AM berbeda.
Masalah dalam mendapatkan konsumen yang sesuai dengan produk juga direspon dengan baik oleh responden KR, AM, dan RF. Mereka menunjukkan bahwa mereka memiliki kendali dan mampu untuk merespon masalah. KR menyikapi masalah dengan terus mencoba mendatangi calon-calon konsumen. Meskipun ia sudah beberapa kali gagal, ia masih terus mencoba. AM menjelaskan cara yang ia lakukan dengan terjun ke lapangan untuk mengetahui apa yang diperlukan dan seperti apa kondisi dari konsumen. RF melakukan perubahanperubahan strategi agar produknya bisa menberi nilai lebih untuk konsumen.

Ketiga responden menunjukkan bahwa mereka memiliki kendali atau respon pada masalah yang dihadapi dengan cara yang berbeda-beda. Responden KR menyikapi masalah eksternal yang datang dari program inkubasi dengan cara membuat peraturan sendiri untuk bisa lebih menentukan sikap. Ia juga menyikapi masalah dengan perasaan tenang karena menurutnya masalah justru membuat perjalanan startupnya lebih seru. Ia juga menjadikan masalah sebagai pembelajaran dan pengalaman yang baik untuk dirinya ke depan. AM menjelaskan ia dan timnya sering mengadakan evaluasi ruitin untuk membahas kinerja timnya. Hal ini untuk membahas dan memperbaiki kekompakan tim. Meskipun menurut peneliti ini bukan sepenuhnya kendali yang dilakukan oleh AM karena evaluasi adalah agenda tim, bukan muncul dari perseorangan. RF menyikapi masalah dengan selalu ingat bahwa ia memiliki tujuan yang hendak dicapai. Ini yang membuatnya tidak mudah menyerah menghadapi masalah. RF juga mencoba melihat sisi positif dari masalah dengan mengambil hikmah. Selain cara-cara itu, RF juga biasanya berdiam diri atau jalan-jalan untuk menenangkan diri. Terlihat dari ketiga 
responden memiliki kendali atas masalah yang dihadapi meskpipun dengan cara yang berbeda. Perbedaan kendali atau respon yang diberikan ini wajar karena situasi dan masalah yang dialami ketiganya tidak sama dan juga untuk merespon suatu masalah bisa dilakukan dengan beragam cara.

Perbedaan sikap dan cara dalam menyelesaikan masalah dapat dipengaruhi oleh dukungan sosial yang diterima oleh responden Bagi $\mathrm{KR}$ dan $\mathrm{RF}$, keduanya menjelaskan mendapatkan dukungan sosial yang membuat mereka lebih gigih dalam menjalankan startup. KR merasakan bahwa dukungan sosial ia rasakan dari tim internalnya yang kian padu dan menjadi semangatnya dalam menyelesaikan masalah. Selain itu ia juga merasakan mendapat dukungan dari pihak lain di luar startup yang membantunya dalam segi fasilitas dan kerja sama demi keberlangsungan startup-nya. Dukungan yang dirasakan oleh $\mathrm{KR}$ tersebut berdampak bagi bagaimana KR menyikapi masalah-masalahnya. Sementara RF merasakan bahwa startup-nya sangat bernilai ketika ia mendapat tawaran pendanaan dari beberapa pihak. Bentuk dukungan seperti itulah yang kemudian menyadarkannya bahwa apa yang ia usahakan ini tidak sia-sia dan layak diperjuangkan. Oleh karena itulah RF menjadi lebih gigih dalam menjalankan dan menyelesaikan masalah startup-nya

Selain strategi coping, bentuk adversity quotient pada diri responden juga dapat terlihat dari karakternya. Karakter tersebut adalah bertanggung jawab, belajar dari pengalaman, teguh pada prinsip, pantang menyerah, dan optimis. Karakterkarakter yang muncul pada diri responden merupakan bentuk positif yang mana menunjukkan adversity quotient yang baik pada responden. Karakter-karakter ini kemudian saling bersinergi dengan strategi coping sehingga menghasilkan daya juang pada responden dalam menjalankan startup.

Berdasarkan penjabaran di atas maka peneliti menyimpulkan bahwa ketiga responden memiliki bentuk adversity quotient yang baik berupa strategi coping dan karakter diri. Ketiga responden menunjukkan strategi coping berupa tindakan untuk menyelesaikan masalah. Memiliki respon dalam menyelesaikan masalah merupakan bagian paling penting dalam adversity quotient yang juga memengerahui aspek-aspek lain. Selain itu ketiga responden juga memiliki bentuk adversity quotient berupa karakter-karakter yang saling bersinergi dengan strategi coping. Karakter-karakter ini memberikan andil positif bagi responden dalam menyelesaikan masalah. Karakter-karakter seperti bertanggung jawab, belajar dari pengalaman, teguh pada prinsip, pantang menyerah, dan optimis membantu responden dalam menghadapi masalah. Selain kedua bentuk adversity quotient tersebut, temuan lain dalam penelitian ini adalah penyebab masalah yang dialami responden serta dampaknya bagi responden, dan juga bagaimana dukungan sosial memengaruhi bentuk adversity quotient pada responden.

\section{Kesimpulan}

Adversity quotient pada pelaku startup di Yogyakarta menunjukkan bahwa responden memiliki kendali atau respon atas permasalahan yang terjadi selama menjalankan startup. Kendali atau cara yang digunakan untuk menyelesaikan permasalahan ini menjadi bagian yang paling menonjol dalam adversity quotient pelaku startup. Mereka menyadari dan juga memiliki kemampuan untuk menyelesaikan masalah yang dihadapi.

Karakter juga merupakan bentuk dari adversity quotient yang muncul dalm penelitian ini. Karakter memiliki pengaruh 
dengan adversity quotient pada pelaku startup. Responden menunjukkan rasa tanggung jawab pada startup-nya, pada jabatan yang diemban, dan nasib anggota lain. Tanggung jawab ini terlihat dari bagaimana sikap responden terhadap perkembangan startup-nya. Responden juga memiliki semangat dan pantang menyerah dalam menyelesaikan masalahmasalah. Walaupun selama menjalankan startup, masalah datang silih berganti, responden menunjukkan kegigihan untuk tetap memperjuangkan startup-nya.

Selain itu, masalah yang dialami memberi dampak pada aktivitas di luar startup. Dampak tersebut tidak terlalu besar hingga mengganggu aktivitas yang lain. Meski memberi dampak, responden masih bisa mengatasinya. Beberapa hal yang menyebabkan dampak masalah tidak terlalu mengganggu adalah responden memiliki kendali atas masalah yang terjadi sehingga punya cara untuk menyelesaikannya.

Masalah yang dialami selama menjalankan startup muncul dari tiga hal, yaitu diri sendiri, tim internal, dan pihak luar. Diri sendiri menjadi penyebab masalah karena keterbatasan kemampuan. Tim internal menjadi penyebab masalah karena kerangka tim yang masih sering berubah-ubah dan belum terlalu kompak. Pihak luar menjadi penyebab masalah karena memiliki tuntutan-tuntutan tertentu kepada tim. Sumber-sumber masalah ini bisa dikatakan sebagaimana mestinya dan tidak mengada-ngada.

Dalam menjalankan startup, responden juga mendapatkan dukungan yang menjadikannya tetap gigih. Dukungan itu muncul dari dari dalam tim internal maupun pihak luar yang bekerjasama. Keberadaan pihak yang mendukung tersebut membuat responden bersemangat dengan startup-nya.
Saran

Kesimpulan yang dipaparkan pada penelitian ini dapat digunakan untuk membantu memetakan faktor-faktor penghambat maupun pendukung dalam proses menjalankan startup, sehingga para pelaku startup dapat memaksimalkan kemampuan diri dalam hal menyelesaikan masalah, persepsi terhadap masalah, dan menyadari dampak masalah yang dialami.

Peneliti selanjutnya diharapkan lebih detail lagi dalam mennggali data adversity quotient pada pelaku startup dan bisa menggunakan skala adversity quotient sebelum melakukan wawancara untuk mengetahui tingkatan adversity quotient pada responden sehingga hasilnya akan diketahui fakor-faktor dominan pada diri responden.

\section{Kepustakaan}

Brinkmann, S., \& Kvale, S. (2015). Interviews learning the craft of qualitative research interviewing. New York: Sage Publications.

Budiman, A. (2016, April 27). Jokowi "pusing" perkembangan "startup" Indonesia tertinggal dari negara lain. Kompas Online. Diunduh dari http://bisniskeuangan.kom pas.com/r ead/2016/04/27/114500026/Jokowi.Pu sing.Perkembangan.Startup.Indones ia.Tertinggal.dari.Negara.Lain

Bungin, B. (2001). Metodologi penelitian sosial. Surabaya: Airlangga University Press.

Cope, J. (2011). Entrepreneurial learning from failure: an intrepretative phenomenological analysis. Journal of Business Venturing, 26(6), 604-623. doi: 10.1016/j.jbusvent.2010.06.002

Everett, J., \& Watson, J. (1998). Small business failure and external risk factors. Small Business Economics, 11(4), 371-390. doi: 10.1023/A:1008065527282 
Fathin, C. A., Achidsti, A., \& Priambodo, D. I. (2016). Analysis of three actors: Roles of government, private sector, and university toward startup growth in Yogyakarta. Jurnal Kebijakan $\mathcal{E}$ Administrasi Publik, 20, 38-55.

Fredland, E., \& Morris, C. (1976). A cross section analysis of small business failure. American Journal of Small Business, 1(1), 7-18. doi: $\underline{10.1177 \% 2 F 104225877600100102}$

Harbison, N. (2014, Agustus 6). Startups and depression: The dark side of entrepreneurship. The Guardian Online. Diunduh dari https://www.theguardian.com/techn ology/2014/aug/06/entrepreneurship -startups-depression

Herdiansyah, H. (2015). Metodologi penelitian kualitatif untuk ilmu psikologi. Jakarta: Salemba Humanika.

Huovinen, J., \& Tihula, S. (2008). Entrepreneurial learning in the context of portfolio entrepreneurship. International Journal of Entrepreneurial Behavior \& Research, 14, 152-171. doi: $\underline{10.1108 / 13552550810874673}$

Kure, E. (2016, Oktober 7). 2020, Jumlah startup di Indonesia capai 13.000. Berita Satu Online. Diunduh dari http://www.beritasatu.com/pelangiramadan-2016/digital-life/3910662020-jumlah-startup-di-indonesiacapai-13000.html

Markman, G., \& Baron, R. (2003). Personentrepreneurship fit: why some people are more successful as entrepreneurs than others. Human Resources Management Review, 13(2), 281-301. doi: 10.1016/S10534822(03)00018-4

Miles, M. B., \& Huberman, A. M. (1994). Qualitative data analysis: An expanded sourcebook (Edisi kedua). Thousand Oaks, CA, US: Sage Publications, Inc. Nawanglupi, C. B., Pawitan, G., Gunawan, A., Widyarini, M., Bisowarno, B. H., \& Iskandarsjah, T. (2015). Global entrepreneurship monitor 2014 Indonesia report. Bandung: UNPAR Press.

Overall, J., \& Wise, S. (2016). The antecedents of entrepreneurial success: A mixed method approach. Journal of Enterprising Culture, 24(3), 209-241.

doi: 10.1142/S0218495816500096

Sari, F. D., \& Sitepu, S. N. (2016). Peran faktor insternal dan faktor eksternal pada keberlangsungan startup bisnis kota Surabaya. Jurnal Manajemen Teori dan Terapan, 9, 12-22.

Shohib, M. (2013). Adversity quotient dengan minat entrepreneurship. Jurnal Ilmiah Psikologi Terapan, 1, 32-39.

Shontell, A. (2013, April 4). The story of a failed startup and a founder driven to suicide. Business Insider. Diunduh dari

http://www.businessinsider.com/jod y-sherman-ecomom-2013$\underline{4}$ ? IR $=T$ \& $r=U S \&$ page $=3$

Sine, W., Haveman, H., \& Tolbert, P. (2005). Risky business? Entrepreneurship in the new independent power sector. Administrative Science Quarterly, 50(2), 200-232. doi: 10.2189/asqu.2005.50.2.200

Stoltz, P. G. (2000). Adversity quotient mengubah hambatan menjadi peluang. Jakarta: Grasindo.

Sugiyono. (2008). Metode penelitian kuantitatif, kualitatif, dan RED. Bandung: Alfabeta.

Ucbasaran, D., Shepherd, D., Lockett, A., \& Lyon, J. (2013). Life after business failure: The process and consequences of business failure for entrepreneurs. Journal of 
IBRAHIM \& SUMARYONO

Management, 39, 163-202. doi: Yusuf, O. (2016, April 6). Startup banyak $\underline{10.1177 / 0149206312457823}$ yang gagal, Bekraf siapkan BEK-UP. Kompas Online. Diunduh dari http://tekno.kompas.com/read/2016/04/06/ 09454647/Startup.Banyak.yang.Gagal.Bekr af.Siapkan.BEK-UP 